\title{
Anti-inflammatory activities of garlic sprouts, a source of a-linolenic acid and 5-hydroxy-L-tryptophan, in RAW 264.7 cells
}

\author{
Joanna Gdula-Argasińska1, Paweł Paśko², Katarzyna Sułkowska-Ziaja³, Katarzyna Kała and \\ Bożena Muszyńska凶
}

1Department of Radioligands, Jagiellonian University Medical College, Kraków, Poland; ${ }^{2}$ Department of Food Chemistry and Nutrition, Medical College, Jagiellonian University, Kraków, Poland; '3Department of Pharmaceutical Botany, Jagiellonian University Medical College, Kraków, Poland

The purpose of this study was to analyze the indolic, phenolic, and fatty acid content and antioxidant activity of garlic sprouts growing in the dark and in the daylight. The pro- or anti-inflammatory properties of the garlic sprout extract were investigated by evaluating the cyclooxygenase-2 (COX-2), prostaglandin E synthase (cPGES), glutathione $S$ transferase (GSTM1), nuclear factor NF-kB, peroxisome proliferator-activated receptors (PPARs), and aryl hydrocarbon receptor (AhR) protein levels in the RAW 264.7 cells activated with lipopolysaccharide (LPS). The highest amount of total indolic (73.56 mg/100 g f.w.) and phenolic compounds (36.23 mg/100 g f.w.) was detected in garlic sprouts grown in the daylight. Studies on antioxidant activity (the FRAP and DPPH method) of garlic sprouts showed that this activity is significantly higher for sprouts grown in full access to light when compared to those grown in the dark. In garlic sprout extracts, a-linolenic acid (ALA) was found to be in greater amount. COX-2 and CPGES level was lower when compared to LPS alone activated cells. After garlic extract treatment, higher level of GSTM1, PPARY, cytosolic p50 and p65 protein, as well as a lower NF-KB p50/p65 activity was noted in the RAW 264.7 cells which suggested PPARs and AhR transrepression mechanism of NF-KB signalling. The obtained results indicate Allium sativum sprouts are a rich source of n-3 fatty acids, indolic and phenolic compounds characterized by anti-inflammatory and antioxidative activity, which may support their high therapeutic and dietary potential.

Key words: Allium sativum sprouts, indolic and phenolic compounds, a-linolenic acid, anti-inflammatory activity, RAW 264.7 cells

Received: 06 March, 2017; revised: 18 July, 2017; accepted: 18 July, 2017; available on-line: 08 September, 2017

e-mail: muchon@poczta.fm

Abbreviations: ALA, a-linolenic acid; AhR, aryl hydrocarbon receptor; COX-2, cyclooxygenase-2; FAs, fatty acids; GSTM1, glutathione $S$ transferase; LPS, lipopolysaccharide; MUFA, monounsaturated fatty acids; NF-KB, nuclear transcription factor $\mathrm{KB}$; PPARs, peroxisome proliferator-activated receptors; CPGES, prostaglandin E synthase; SFA, saturated fatty acids; UNSFAs, unsaturated fatty acids

\section{INTRODUCTION}

Garlic, known to humans for more than 10,000 years, is one of the oldest cultivated plants (Durak et al., 2002; Durak et al., 2004). The history of classification of the Allium genus dates back to the Linnaeus' time (the year of 1753) and has repeatedly been changed ( $\mathrm{Li}$ et al., 2010). In recent years, studies on morphology, anatomy, serology, and ecology have created the current system of classification of the Allium genus in which it belongs to the Amaryllidaceae family (Angiosperm Phylogeny Group, 2009). The origin of the Allium species is questionable, and there are hypotheses that these species come from the Middle East or Central Asia. Recent studies indicate that the northwestern part of the Tien Shan Mountains located on the border of Kyrgyzstan, Kazakhstan, and China is the most probable place of origin of garlic (Nagini, 2008). The cultivation of garlic has become popular in the Mediterranean regions from where it spread to sub-tropical areas of Africa. From Central Asia, it also moved to China and Japan. It was brought to North America from the Mediterranean regions by the colonists (Block, 2010; Li et al., 2010). A great collection of varieties occurs in California. In Poland, garlic is a common crop. Pharmaceutical raw materials are fresh onions or garlic cloves of Allia Sativa bulbus, Allia Sativa pulvis powdered garlic, or garlic oil (Bat-Chen et al., 2010).

People started assessing properties of garlic as early as 1858, when Louis Pasteur documented its antibacterial activities that were used during World War I and II (for the prevention of gangrene) (Sovova \& Sova, 2004; Edwards et al., 2005; Nagini, 2008). These days, garlic is one of the most widely used plant products purchased by consumers for culinary, pro-health, or therapeutic reasons. Although the knowledge about health benefits of garlic dates to antiquity, there is still a need to study activity of various compounds present in this plant. Today, the goal of research is to provide medical justification for the use of garlic, assessment of its composition, and documentation of the mechanisms of its action in the human organism (Durak et al., 2002; Edwards et al., 2005).

The main components of fresh garlic cloves are as follows: water (approximately 65\%), carbohydrates, especially fructans - fructose polymers (approximately 28\%) - e.g., inulin (approximately 5\%), fiber, protein, and fats. One can also find flavonoids, mucus compounds, steroidal saponins, free amino acids, in addition to many organic sulfur compounds occurring in the raw material. Furthermore, garlic bulbs include the following vitamins: $\mathrm{A}, \mathrm{B}_{1}, \mathrm{~B}_{2}, \mathrm{PP}$, and C (31 mg/100 $\mathrm{g}$ of garlic); macronutrients such as phosphorus, potassium, calcium, magnesium, sodium; and trace elements such as zinc, selenium, iron (Nagini, 2008). Organic selenium compounds occurring in $A$. sativum show antitumor activity; $\gamma$-glutamyl-methylcysteine (GMCS) is the main compound, which, similarly to a sulfur analog, may be converted by $\gamma$-glutamyl transpeptidase into further derivatives. Garlic oil content in bulbs depends on the environmental conditions ranging from $0.005 \%$ to $0.4 \%$ (Iciek et al., 2009). 
While the composition of garlic bulbs is widely studied, according to the knowledge that we now have, there is lack of information on the content of biologically active compounds in garlic sprouts. In recent years, the consumption of sprouts - the atypical vegetable, has received attention as functional food because of its nutritive value served by amino acids, fiber, trace elements, vitamins, flavonoids, and phenolic acids (Paśko et al., 2009; Paśko et al., 2014).

Therefore, the purpose of the study presented here was to analyze biologically active compounds, such as the indolic and phenolic compounds, as well as fatty acids, and to determine the antioxidant and anti-inflammatory properties of extracts from garlic sprouts. The impact of light (i.e., germination was carried out in daylight and in the dark) on the germination and the content of physiologically active compounds was also evaluated.

\section{MATERIALS AND METHODS}

Plant material. Plant material included sprouts of $\mathrm{Al}$ lium sativum L. Voucher specimens were deposited at the Department of Food Chemistry and Nutrition, Faculty of Pharmacy, Medical College, Jagiellonian University with reference number AS/PP/PL 1052 to $A$. sativum (harvested in Italy).

Sprout harvesting. Detailed procedure of the sprouts' harvesting was published previously (Pasko et al., 2015). Garlic seeds were immersed in commercially available water $\left(\mathrm{HCO}_{3}{ }^{-}=131.06 \mathrm{mg} / \mathrm{L} ; \mathrm{F}^{-}=0.07 \mathrm{mg} / \mathrm{L} ; \mathrm{Mg}^{2+}=5.62\right.$ $\left.\mathrm{mg} / \mathrm{L} ; \mathrm{Ca}^{2+}=41.69 \mathrm{mg} / \mathrm{L} ; \mathrm{Na}^{+}=9.65 \mathrm{mg} / \mathrm{L}\right)$ for $3 \mathrm{~h}$ and then placed in plastic vessels. Sprouts were grown for 10 days after seeding at the controlled temperature of $24 \pm 2^{\circ} \mathrm{C}$ and watered daily. All sprouts were stored under natural light conditions or in the darkness.

Reagents. All chemicals used were of analytical grade. Magnesium sulfate, chloroform, and ammonium acetate were purchased from POCh (Gliwice, Poland). Standards of indole compounds, such as L-tryptophan, 5-hydroxy-L-tryptophan, 5-methyl-tryptophan, serotonin, melatonin, tryptamine, 5-methyl-tryptamine, indole, triphenyltriazine (TPTZ) - 2,4,6-tris(2-pyridyl)1,3,5-triazine, 1,1-diphenyl-2-pic-rylhydrazyl (DPPH), 6-hydroxy-2,5,7,8-tetramethyl-2-carboxylic acid (trolox), sodium peroxydisulfate, Folin-Ciocalteu reagent, and fatty acid methyl ester standards were obtained from Sigma-Aldrich (St. Louis, MO, USA), and all of them were of the HPLC grade. Phenolic acid standards such as $p$-coumaric, ferulic, $p$-hydroxybenzoic, vanillic, and 3,4-dihydrophenylacetate acids were purchased from Fluka (Chemie AG) and those of caffeic, chlorogenic, cinnamic, o-coumaric, protocatechuic, sinapic, gallic, and syringic acids were from Sigma-Aldrich (St. Louis, MO, USA). Methanol, acetic acid, n-hexane, petroleum ether, and dichloromethane were obtained from Merck (Darmstadt, Germany). Quadruple-distilled water with conductivity of less than $1 \mu \mathrm{S} / \mathrm{cm}$ was obtained using an S2-97A2 distillation apparatus, ChemLand (Stargard Szczeciński, Poland).

RP-HPLC analysis of indole compounds. Fresh biomass (3 g of garlic sprouts cultured in daylight and in darkness, and garlic seeds) was ground in a mortar and then subjected to extraction with petroleum ether to remove lipids (Muszyńska et al., 2011; Muszyńska et al., 2012). Defatted material was extracted in a glass percolator by methanol. The obtained extract was evaporated (Büchi evaporator, Germany) under pressure of $200 \mathrm{mbar}$ at $40^{\circ} \mathrm{C}$, down to dryness. The concentrat- ed analyte was dissolved in methanol and transferred through Whatman No. 3 filter paper. The extracts were quantitatively dissolved in $1.5 \mathrm{~mL}$ of a solvent system (methanol/water/ammonium acetate 15:14:1, v/v/v) and subjected to separation by RP-HPLC using the Hitachi HPLC (Merck, Japan) equipped with a pump (type L-7100), the Purospher ${ }^{\circledR}$ RP-18 column $(4 \times 200 \mathrm{~mm}$, $5 \mu \mathrm{m})$ kept at $25^{\circ} \mathrm{C}$ and UV detector operated at $\lambda=280$ $\mathrm{nm}$. The isocratic separation was applied with mobile phase as follows: methanol/water/ammonium acetate $(15: 14: 1, \mathrm{v} / \mathrm{v} / \mathrm{v})$, at a flow rate of $1 \mathrm{~mL} / \mathrm{min}$. The quantitative analysis of indole compounds was performed using a calibration curve with the assumption of the linear size of the area under the peak and the concentration of the reference standard. The results were expressed in $\mathrm{mg} / 100 \mathrm{~g}$ of fresh weight (f.w.).

RP-HPLC analysis of phenolic compounds. The extracts were obtained in the same way as for indole compounds and were analyzed for phenolic acid contents using the RP-HPLC method. These analyses were carried out according to the procedure developed by EllnainWojtaszek and Zagórka (1999), with some modifications (Muszyńska et al., 2016). Briefly, the analytical conditions were as follows: HPLC VWR Hitachi-Merck apparatus autosampler L-2200, pump L-2130, LiChrospher RP-18e column $(250 \mathrm{~mm} \times 4 \mathrm{~mm}, 5 \mu \mathrm{m})$ thermostated at $25^{\circ} \mathrm{C}$, column oven L-2350, diode array detector L-2455 at UV range $200-400 \mathrm{~nm}$. The mobile phase was comprised of solvent A: methanol $/ 0.5 \%$ acetic acid 1:4 (v/v); solvent B: methanol. Gradient conditions were as follows (A/B ratio[\%]): 100:0 for 0-20 $\mathrm{min}$; 80:20 for $35 \mathrm{~min}$; 70:30 for $45 \mathrm{~min}$; $60: 40$ for $55 \mathrm{~min}$; 50:50 for $60 \mathrm{~min}$; 25:75 for $65 \mathrm{~min}$; 0:100 for 70-75 $\mathrm{min}$; 100:0 for 80-90 min.

Extract preparation for antioxidant analysis. Garlic seed and sprout samples (3 g) were extracted with $30 \mathrm{~mL}$ of methanol for $3 \mathrm{~h}$. The obtained extracts were decanted, centrifuged, and stored in the darkness in a freezer at $-24^{\circ} \mathrm{C}$, and were later used for estimating total antioxidant activity (FRAP, DPPH) and total phenolic content.

Determination of total phenols. Total phenols were determined colorimetrically using the Folin-Ciocalteau reagent, as described previously (Paśko et al., 2009). Total phenol assay was conducted by mixing $2.7 \mathrm{~mL}$ of deionized water, $0.3 \mathrm{~mL}$ of extracts, $0.3 \mathrm{~mL}$ of $7 \mathrm{~g} / 100 \mathrm{~g}$ $\mathrm{Na}_{2} \mathrm{CO}_{3}$, and $0.15 \mathrm{~mL}$ of the Folin-Ciocalteu reagent. The absorbance of mixture was measured at 725 and $760 \mathrm{~nm}$ using the Jasco UV-530 spectrophotometer. A standard curve was prepared with gallic acid. The final results were given as gallic acid equivalents ( $\mathrm{mg} / \mathrm{g}$ ).

Total antioxidant activity (FRAP method). FRAP assay was carried out according to Benzie and Strain (1996) and modified for 48-well plates and an automated reader (Synergy-2, BioTek, USA) with syringe rapid dispensers. Briefly, the oxidant in the FRAP assay (reagent mixture) was freshly prepared just before use and was comprised of a ferric chloride solution $(20 \mathrm{mmol} / \mathrm{L})$, 2,4,6-tripyridyl-striazine (TPTZ) solution (10 $\mathrm{mmol} / \mathrm{L}$ TPTZ in $40 \mathrm{mmol} / \mathrm{L} \mathrm{HCl}$, and an acetate buffer $(\mathrm{pH}=3.6)$ in a proportion of $5: 5: 10$, respectively. To each plate, $0.4 \mathrm{~mL}$ of the acetate buffer ( $\mathrm{pH}$ 3.6) was dispensed, followed by $50 \mu \mathrm{L}$ of the sample (methanol extracts), standard or blank. The plate was conditioned at $37^{\circ} \mathrm{C}$ for $2 \mathrm{~min}$ and then $0.2 \mathrm{~mL}$ of the reagent mixture was added and shaken for $30 \mathrm{~s}$; afterward, the absorbance at $593 \mathrm{~nm}$ was measured with kinetic mode for $15 \mathrm{~min}$. The final results were expressed as $\mathrm{mmol} \mathrm{Fe}{ }^{2+} / \mathrm{g}$ of fresh weight. 
Total antioxidant activity (DPPH method). The scavenging activity of garlic seed and sprout samples was measured as previously described by Alvarez-Suarez and coworkers (2012), with a modification as follows. A $100 \mu \mathrm{L}$ of sample solution $(2-30 \mathrm{mg} / \mathrm{mL}$, final concentration) was diluted to $500 \mu \mathrm{L}$ with $70 \%$ methanol and vigorously mixed with $400 \mu \mathrm{L}$ of the DPPH solution in methanol $(0.2 \mathrm{mmol})$. The mixtures were left in the dark at $30^{\circ} \mathrm{C}$ for $24 \mathrm{~h}$, after which the absorbance of the solution was measured at $517 \mathrm{~nm}$. The sample blank was comprised of $600 \mu \mathrm{L}$ of $70 \%$ methanol and $400 \mu \mathrm{L}$ of DPPH, whereas the sample contained $100 \mu \mathrm{L}$ of evaluated samples, $500 \mu \mathrm{L}$ of $70 \%$ methanol, and $400 \mu \mathrm{L}$ of methanol. The values are expressed as the mean of three IC50 values (concentration causing 50\% inhibition) of each sample determined graphically.

Cultured cells. Mus musculus murine macrophages were used (American Type Cell Culture: RAW 264.7, TIB-71). RAW 264.7 cells were cultured in Dulbecco's Modified Eagle's Medium supplemented with 10\% FBS and $1 \%$ antibiotic solution $(100 \mathrm{IU} / \mathrm{mL}$ penicillin, $0.1 \mu \mathrm{g} / \mathrm{mL}$ streptomycin) (ATTC, Manassas, VA, USA). The cells were maintained at $37^{\circ} \mathrm{C}$ in a humidified atmosphere of $5 \% \mathrm{CO}_{2}$ in air, and were finally seeded into a 6-well plate (Sarstedt, Nümbrecht, Germany) at a density of $5 \times 10^{5}$ cells/well in $2 \mathrm{~mL}$ of medium. At every step of the procedure, cell morphology was studied by an inverted light microscope (Olympus, Tokyo, Japan). The cell viability during culturing was assessed with Trypan Blue Exclusion Test. Macrophages were activated by LPS at 1 $\mu \mathrm{g} / \mathrm{mL}$ for $24 \mathrm{~h}$. After activation, Allium sativum methanol extracts (10 and $25 \mu \mathrm{g} / \mathrm{mL}$ ) were added to the cells and incubated for $24 \mathrm{~h}$.

Western blot. Cell lysates were prepared using an M-PER buffer (Thermo Scientific, Walthman, MA, USA) with protease inhibitor cocktail set III (Calbiochem, Merck, Germany). Protein concentrations were determined using the Bradford reaction. Aliquots (40 $\mu \mathrm{g})$ were solubilized in a Laemmli buffer with $2 \%$ mercaptoethanol (BioRad, Hercules, CA, USA) and subjected to $10 \%$ SDS-polyacrylamide gel electrophoresis as described earlier (Gdula-Argasińska et al., 2015a,b). We used primary antibodies, such as anti-cyclooxygenase 2 (COX2), anti-gluthatione S transferase (GSTM1), anti-cytosolic prostaglandin E2 synthase (cPGES), anti-aryl hydrocarbon receptor (AhR), and anti- $\beta$-actin (GeneTex Inc., Irvine, CA, USA) diluted 1:1000, and anti-NF-кB p50, anti-NF-kB p65, anti-PPAR $\delta$, and anti-PPAR $\gamma$ (Cayman Chemicals, Ann Arbor, MI, USA) diluted 1:100 in Signal+ for Western Blot (Gene'Tex); the secondary antibody was Easy Blot anti-rabbit IgG (HRP) diluted 1:2000 in Signal+ for Western Blot (GeneTex). Proteins were detected using a western blotting detection kit, Clarity Western ECL Luminol Substrate (Bio-Rad). The integrated optical density of the bands was quantified using a Chemi Doc Camera with Image Lab software (BioRad).

Analysis of fatty acids. Cell membranes were prepared by hypotonic hemolysis at $4^{\circ} \mathrm{C}$ in $10 \mathrm{mmol}$ Tris with $\mathrm{pH} 7.4$ and then isolated by centrifugation $(10000 \times g, 15 \mathrm{~min})$ according to the method proposed by Graham (2006). Powdered biomass of garlic sprouts cultured under light and in the darkness, garlic seeds ( $1 \mathrm{~g})$, and RAW 264.7 cell membranes were extracted with a chloroform-methanol solution (2:1, v/v). Fatty acid methyl esters (FAME) were synthesized using 10\% $\mathrm{BF}_{3}$ in methanol at $100^{\circ} \mathrm{C}$. Heptadecanoic acid was used as an internal standard. FAME analyses were performed using gas chromatography (GC)-Agilent 6890N with a J\&W DB-23 capillary column $(60 \mathrm{~m}$, ID $0.25 \mathrm{~mm}$, $0.25 \mu \mathrm{m}$ ) and FID detector, as described earlier (GdulaArgasińska et al., 2015a; Gdula-Argasińska et al., 2015b). Retention times of FAME standards were used to identify fatty acids. Peak areas were measured using an integrator function (ChemStation). The results for fatty acid composition were expressed as relative percentage of total fatty acids.

NF-кB transcription factor activity. RAW 264.7 cells $\left(1 \times 10^{7} / \mathrm{mL}\right)$ were activated in triplicates with LPS for $24 \mathrm{~h}$ and incubated with garlic sprout extracts for $24 \mathrm{~h}$. After incubation, cells were removed by scraping and centrifuged for $5 \mathrm{~min}$ at $100 \times \mathrm{g}$ at $4^{\circ} \mathrm{C}$. The nuclear extracts from cell pellets were extracted using a Nuclear Extraction Kit, according to the manufacturer's instructions (Cayman Chemical, Ann Arbor MI, USA).

NF-KB p65 and p50 transcription factor activity was detected in an ELISA format using dsDNA-bound transcription factor with primary antibodies against the $\mathrm{NF}_{-\mathrm{KB}} \mathrm{p} 65$ and p50 (Cayman Chemical). A secondary antibody conjugated with HRP was added to provide a colorimetric readout at $450 \mathrm{~nm}$. Using the Omega plate reader (BMG LABTECH, San Diego, CA, USA), absorbance changes were measured before and after adding the stop solution reagent.

Data were expressed as fold changes, when compared to the control.

Statistics. Values are presented as means \pm S.D. All experiments were performed four times. Statistical significance was evaluated using a one-way ANOVA with Scheffe' post hoc test. Calculations were done using STATISTICA 12 (StatSoft Inc., Tulsa, OK, USA), and statistical significance was established as $p \leq 0.05$.

\section{RESULTS AND DISCUSSION}

Inflammation is associated with many disorders such as the inflammatory diseases, metabolic syndrome, atherosclerosis, and cancer. Mechanisms to curtail the inflammatory response and promote its resolution are of immense interest. Searching for the new natural anti-inflammatory, as well as pro-resolving substances that act without side effects, seems to be very important. Garlic extracts have been recently reported to be effective in cardiovascular diseases and to possess many other biological activities, including antimicrobial, antioxidant, anticarcinogenic, and immunomodulatory activities (Durak et al., 2004; Bat-Chen et al., 2010; Park et al., 2014).

Among the analyzed indole compounds in extracts from garlic sprouts (germination without light and at daylight), we detected the presence of L-tryptophan, 5-hydroxy-L-tryptophan, and melatonin. A greater content of indolic and phenolic compounds was found in extracts from the material obtained during germination under daylight and their total content was 73.56 $\mathrm{mg} / 100 \mathrm{~g}$ and $36.23 \mathrm{mg} / 100 \mathrm{f} . \mathrm{w} .$, respectively (Table 1).

For the material obtained without daylight, the indolic and phenolic compounds' content was decreased by half, that is, $33.65 \mathrm{mg} / 100 \mathrm{~g}$ and $29.44 \mathrm{mg} / 100 \mathrm{f.w}$., respectively (Table 1$)$. The lowest total content of compounds studied was determined in the control garlic seeds, where the indolic and phenolic compounds accounted for $13.19 \mathrm{mg} / 100 \mathrm{~g}$ and $0.01 \mathrm{mg} / 100 \mathrm{~g}$ f.w., respectively (Table 1$)$. In the garlic sprout extracts obtained from sprouts grown under daylight, we observed a greater content of such indole compounds as 5-hydroxy-L-tryptophan (51.94 mg/100 g f.w.), L-tryptophan (20.02 mg/100 g f.w.), and melatonin (1.60 mg/100 g 
Table 1. Indole and phenolic compounds detected by the RP-HPLC method in garlic sprouts (mg/100 g f.w.)

\begin{tabular}{|c|c|c|c|}
\hline Indole compounds & Garlic sprouts (daylight) & Garlic sprouts (darkness) mg/100 g f.w. & Garlic seeds \\
\hline L-Tryptophan & $20.02 \pm 0.80^{*}$ & $6.11 \pm 0.62^{*, *}$ & $0.01 \pm 0.00^{*, * *}$ \\
\hline 5-Hydroxy-L-tryptophan & $51.94 \pm 0.58^{*}$ & $26.43 \pm 1.57^{* * *}$ & $12.36 \pm 0.44^{* * * *}$ \\
\hline Melatonin & $1.60 \pm 0.02^{*}$ & $1.12 \pm 0.01^{* *}$ & $0.83 \pm 0.00^{* * * *}$ \\
\hline Total content & $73.56 \pm 25.47$ & $33.65 \pm 13.41$ & $13.19 \pm 8.15$ \\
\hline \multicolumn{4}{|l|}{ Phenolic compounds } \\
\hline Gallic acid & $1.06 \pm 0.01 *$ & $0.79 \pm 0.01^{*, *}$ & $0.01 \pm 0.00^{*, * *}$ \\
\hline 3,4-dihydroxyphenylacetic acid & $35.17 \pm 0.16^{*}$ & $28.66 \pm 0.04^{*}$ & - \\
\hline Total content & $36.23 \pm 24.12$ & $29.44 \pm 19.71$ & $0.01 \pm 0.00$ \\
\hline
\end{tabular}

Data are presented as the mean \pm S.D. (standard deviation); $\mathrm{n}=4$ repetitions. Asterisks ${ }^{*}{ }^{* *}$ denote statistical significance, $p<0.05$

f.w.) (Table 1). In the sprouts obtained by growing them in the dark, similar compounds were determined; however, their quantities were decreased nearly by half. The lowest quantity - and only for two compounds, i.e. 5-hydroxy-L-tryptophan and melatonin, was determined in extracts from the garlic seeds (control): $12.36 \mathrm{mg} / 100 \mathrm{~g}$ and $0.83 \mathrm{mg} / 100 \mathrm{~g}$ f.w., respectively (Table 1).

Indole compound content in $A$. sativum bulbs derived from different crops in the selected regions of the world, as well as in the commercially available granulated garlic, has been already analyzed. In the studies conducted by Muszyńska and coworkers (2014) similar results were reported; however, the study presented here reveals higher levels of L-tryptophan in the sprouts than in the bulbs.

In the human organism, in the central nervous system, tryptophan is converted into serotonin and melatonin. L-tryptophan undergoes the following three major transformations: decarboxylation leading to the formation of tryptamine, hydroxylation with simultaneous conversion into 5-hydroxy-L-tryptophan, which forms serotonin, and fracture of the indole ring leading to the release of kynurenine. It also acts as a precursor of niacin (vitamin $\mathrm{B}_{3}$ or PP). Moreover, sedative and antidepressant activity of this amino acid has been known for long (5-HTP passes through the blood-brain barrier and is metabolized to serotonin) (Stone et al., 2003; Kaneez \& Arshad, 2007).

5-Hydroxy-L-tryptophan, as a direct precursor of serotonin, is easily absorbed with food, and passes the blood-brain barrier in the central nervous system where it is converted to serotonin. In several countries, it is applied as a dietary supplement having an antidepressant and hypnotic activity, and is also used to decrease appetite (Turner et al., 2006; Muszyńska et al., 2012). In the study presented here, amounts of this metabolite that were determined in extracts of garlic sprouts were also higher in comparison to the previously studied bulbs of this material, where the maximum amount was estimated at $13.40 \mathrm{mg} / 100 \mathrm{~g} \mathrm{f.w.,} \mathrm{and} \mathrm{was} \mathrm{present}$ at a nearly the same order of magnitude in the seed extracts.
In the studied garlic bulb samples, we found the presence of melatonin up to $0.96 \mathrm{mg} / 100 \mathrm{~g} \mathrm{~d}$.w. in garlic bulbs from Mexico (Muszyńska et al., 2014), and they were particularly lower compared to the content of this compound in sprouts (up to $1.60 \mathrm{mg} / 100 \mathrm{~g}$ d.w.), and comparable to their content in seeds $(0.83 \mathrm{mg} / 100 \mathrm{~g}$ d.w.). Melatonin (N-acetyl-5-methoxytryptamine) is produced in pinealocytes of the pineal gland, in the retina and the gastrointestinal tract. This compound is involved in the regulation of sleep and one's mood; it coordinates the work of the biological clock controlling the circadian rhythm and acts against aging, regenerates the processes of cell renewal, and has anti-cancer properties (Espositi \& Cuzzocrea, 2010). Biological effects are induced through activating of the melatonin receptors. Melatonin is available as a therapeutic product used in sleep disorders associated with time zone change or shift work. Melatonin is also a powerful antioxidant that retards the aging process by neutralizing free radicals, e.g., hydroxyl radicals. In neurodegenerative diseases, melatonin plays a neuroprotective role (Espositi \& Cuzzocrea, 2010). Melatonin level decreases after the age of 35 and significantly drops after 40 years of age, which begins the process of human organism's aging and increases the risk of cancer development. Also, melatonin and indole derivatives have anti-inflammatory and analgesic properties (Espositi \& Cuzzocrea, 2010; Muszyńska et al., 2011; Singhal et al., 2012).

Indole compounds were studied in rutabaga and kohlrabi sprouts. Serotonin was observed solely in rutabaga sprouts, in rather small amounts of $0.10 \pm 0.00$ to $0.38 \pm 0.06 \mu \mathrm{g} / 100 \mathrm{~g}$ f.w. In 8 -day sprouts of rutabaga and kohlrabi, melatonin concentrations were at the level of $0.51 \pm 0.11$ and $0.70 \pm 0.02 \mu \mathrm{g} / 100 \mathrm{~g}$ f.w., respectively (Paśko et al., 2014). Therefore, indole compound content in these materials was established at a very low level in comparison to garlic sprouts. In extracts of garlic sprouts, we reported the presence of two phenolic acids: gallic and 3,4-dihydroxyphenylacetic acids. In extracts of the seeds, gallic acid was determined in a very small

Table 2. Total antioxidant activity of garlic sprouts from daylight and from darkness detected by the FRAP, TP and DPPH methods

\begin{tabular}{lccc}
\hline & $\begin{array}{c}\text { FRAP } \\
\text { (mmol Fe}\end{array}$ & $\begin{array}{c}\text { TP } \\
\text { (mg f.w.) }\end{array}$ & $\begin{array}{c}\text { DPPH } \\
\text { (IC50 mg) }\end{array}$ \\
\hline Garlic seeds & $1.33 \pm 0.07$ & under detection limit & $11.18 \pm 0.07$ \\
\hline Garlic sprouts (daylight) & $2.41 \pm 0.16$ & $0.09 \pm 0.00$ & $12.78 \pm 0.43$ \\
\hline Garlic sprouts (darkness) & $1.57 \pm 0.06$ & under detection limit & $14.00 \pm 0.60$ \\
\hline
\end{tabular}


Table 3. Fatty acid content [\%] in Allium sativum sprouts from daylight and darkness cultures. Means \pm S.D., $n=4$

\begin{tabular}{lcc}
\hline FA & Garlic sprouts daylight & Garlic sprouts darkness \\
\hline C10:0 & $1.9 \pm 0.4$ & $1.1 \pm 0.1$ \\
\hline C12:0 & $1.4 \pm 0.2$ & $1.9 \pm 0.3$ \\
\hline C14:0 & $3.7 \pm 0.5$ & $9.6 \pm 1.1$ \\
\hline C16:0 & $11.5 \pm 0.7$ & $7.9 \pm 0.8$ \\
C18:0 & $10.1 \pm 1.2$ & $4.1 \pm 0.5$ \\
C18: 1 & $8.1 \pm 0.8$ & $7.9 \pm 1.0$ \\
\hline C18:2n-6 & $5.1 \pm 1.1$ & $2.4 \pm 0.2$ \\
\hline C18:3n-3 & $58.5 \pm 3.2$ & $65.1 \pm 2.6$ \\
\hline
\end{tabular}

amount established at only $0.01 \mathrm{mg} / 100 \mathrm{~g}$ f.w. Similarly as for the indole compounds, the greater amounts of phenolic acids, that is up to $35.17 \mathrm{mg} / 100 \mathrm{~g}$ f.w. (3,4-dihydroxyphenylacetic acid) were present in the extracts from sprouts obtained by growth under daylight.

Our studies on the antioxidant activity (the FRAP and DPPH method) of garlic sprouts indicated that this activity is significantly higher for sprouts grown in full access to light when compared to those grown in the dark. FRAP values of garlic seeds and sprouts varied between 1.33 and $2.41 \mathrm{mmol} \mathrm{Fe}{ }^{2+} / \mathrm{g}$ f.w. (Table 2), and were lower than those of the amaranth sprouts (Paśko et al., 2009). DPPH (IC50) scavenging activity in garlic seeds and sprouts varied between 11.18 and 14.00, and was lower than those reported by Qieiroz and coworkers (2009) in fresh garlic.

The compounds determined for both groups of metabolites show an antioxidant and anti-inflammatory activity. High content of indole compounds may be responsible for such a strong therapeutic effect.

In garlic sprout extracts, $\alpha$-linolenic acid (ALA) was found to be in a greater amount (58\% from daylight sprouts; 65\% from those grown in darkness). Also, the palmitic, stearic, and oleic acids were observed in higher amounts (near 10\%) (Table 3). In Kamanna \& Chandrasekhara's study (1980), the unsaturated fatty acids (UNSFA) content in garlic varied from $71.6 \%$ in phospholipid, to $80.4 \%$ in neutral lipid fraction. The authors had detected not only the linoleic acid as a predominant acid, but had also found that the $\alpha$-linolenic acid was high in the glycolipid fraction $(37.5 \%)$. Our data agree with their observation that the oleic, linoleic, and linolenic acids are the major unsaturated fatty acids found in garlic.

After incubation with garlic sprout extracts and after activation with LPS, the fatty acid content in the RAW 264.7 cell membranes differs significantly when compared to control or LPS cells (Table 4). We observed a decrease of saturated fatty acids (SFA) and an increase of UNSFA in all cells treated with $A$. sativum extracts alone or activated with LPS. Also, the n-3 fatty acid level was higher, particularly in samples treated with garlic extracts of sprouts cultivated in darkness (Table 4). Changes of the fatty acid profile of the macrophage cell membranes after incubation with garlic sprouts may be due to a high $\alpha$-linolenic acid content in $A$. sativum extracts. The altered profile of fatty acids in the membrane might be caused by lipid mediators generated during inflammation, with the production of the resolving mediator classes.

$\alpha$-Linolenic acid is an essential fatty acid and a precursor of long-chain fatty acids (eicosapentaenoic and docosahexaenoic acid) that are synthetized by a series of desaturation and elongation reactions. The anti-inflammatory and anti-cancer activity of ALA was has been shown in the in vitro and in vivo studies (Yang et al., 2013; Anand \& Kaithwas, 2014). Also, the beneficial effects of n-3 polyunsaturated fatty acids (PUFAs) were proven in several observational and experimental studies. PUFAs and their eicosanoid derivatives may play a significant role in modulating the inflammatory response and act as pro-resolving mediators of inflammation (Gdula-Argasińska et al., 2013; Gdula-Argasińska et al., 2015a; Gdula-Argasińska et al., 2015b; Serhan 2015; Gdula-Argasińska et al., 2016a; Gdula-Argasińska et al., 2015b).

Statistically, the highest amount of COX-2 was observed in the RAW 264.7 cells incubated with LPS. Significant repression of this protein was noted both, in the cells treated with garlic sprout extracts alone and in the cells activated with LPS ( $p=0.001)$. The lowest level of COX-2 was detected in the samples supplemented with $10 \mu \mathrm{g} / \mathrm{mL}$ Allium sprout extracts obtained from sprouts grown in darkness $(p=0.02)$ (Fig. 1A). In the samples incubated with LPS, a statistically higher level of cPGES was observed when compared to other samples $(p=0.001)$. A greater repression of this protein was noted

Table 4. Fatty acids content [\%] in membranes of RAW264.7 cells activated with LPS and supplemented with garlic extracts. Means \pm S.D., $\mathrm{n}=4$

\begin{tabular}{|c|c|c|c|c|c|c|}
\hline & SFA & UNSFA & MUFA & $n-3 F A$ & $\mathrm{n}-6 \mathrm{FA}$ & $n-3 / n-6$ \\
\hline control & $56.7^{*} \pm 1.3$ & $43.3^{*} \pm 1.3$ & $9.2^{*} \pm 0.8$ & $29.4^{*} \pm 2.0$ & $4.7 \pm 1.1$ & $6.3^{*} \pm 0.4$ \\
\hline LPS & $57.7^{*} \pm 1.1$ & $42.3^{*} \pm 0.9$ & $21.1^{* *} \pm 2.5$ & $14.0^{* *} \pm 0.5$ & $7.2 \pm 1.3$ & $0.6^{* *} \pm 0.2$ \\
\hline Garlic sprouts daylight $(10 \mu \mathrm{g} / \mathrm{mL})$ & $38.4^{* *} \pm 0.8$ & $61.6^{* *} \pm 1.4$ & $18.8^{* *} \pm 0.8$ & $37.6^{* * *} \pm 2.1$ & $5.2 \pm 1.1$ & $7.4^{*} \pm 1.8$ \\
\hline Garlic sprouts daylight $(10 \mu \mathrm{g} / \mathrm{mL})+$ LPS & $40.2^{* *} \pm 1.6$ & $59.8^{* *} \pm 1.3$ & $26.1^{* * *} \pm 2.2$ & $29.1^{*} \pm 1.5$ & $4.6 \pm 0.5$ & $6.5^{*} \pm 1.0$ \\
\hline Garlic sprouts daylight $(25 \mu \mathrm{g} / \mathrm{mL})$ & $37.4^{* *} \pm 2.4$ & $62.6^{* *} \pm 3.7$ & $24.7^{* * *} \pm 1.5$ & $32.1^{*} \pm 1.9$ & $5.8 \pm 0.6$ & $5.5^{*} \pm 0.3$ \\
\hline Garlic sprouts daylight $(25 \mu \mathrm{g} / \mathrm{mL})+$ LPS & $36.7^{* *} \pm 0.9$ & $63.3^{* *} \pm 2.8$ & $21.7^{* *} \pm 0.8$ & $37.0^{* * *} \pm 0.5$ & $4.6 \pm 0.4$ & $8.0^{*} \pm 0.7$ \\
\hline Garlic sprouts darkness $(10 \mu \mathrm{g} / \mathrm{mL})$ & $31.8^{* * *} \pm 0.6$ & $68.2^{* * *} \pm 3.4$ & $17.0^{* *} \pm 0.8$ & $45.5^{* * *} \pm 2.5$ & $5.6 \pm 0.6$ & $8.5^{*} \pm 0.7$ \\
\hline Garlic sprouts darkness $(10 \mu \mathrm{g} / \mathrm{mL})+$ LPS & $36.3^{* *} \pm 0.6$ & $63.7^{* *} \pm 2.8$ & $22.3^{* *} \pm 1.3$ & $36.4^{* * * *} \pm 6.1$ & $5.0 \pm 1.1$ & $7.3^{*} \pm 1.1$ \\
\hline Garlic sprouts darkness $(25 \mu \mathrm{g} / \mathrm{mL})$ & $36.5^{* *} \pm 2.0$ & $63.5^{* *} \pm 1.9$ & $16.1^{* *} \pm 2.0$ & $39.1^{* * *} \pm 3.4$ & $8.3 \pm 1.9$ & $5.1^{*} \pm 0.7$ \\
\hline Garlic sprouts darkness $(25 \mu \mathrm{g} / \mathrm{mL})+$ LPS & $39.0^{* *} \pm 3.0$ & $61.0^{* *} \pm 2.7$ & $18.3^{* *} \pm 1.6$ & $37.0^{* * *} \pm 0.9$ & $5.7 \pm 0.7$ & $6.9^{*} \pm 0.4$ \\
\hline
\end{tabular}

SFA, saturated fatty acids; UNSFA, unsaturated fatty acids; MUFA, monounsaturated fatty acids. Asterisks ${ }^{*}, * * * *$ denote statistical significance, $p<0.05$ 
in samples treated with the Allium extract from sprouts cultivated in the dark (Fig. 1B).

A lower level of COX-2 and cPGES in the cells supplemented with garlic extracts when compared to LPS samples may be due to the high level of $\alpha$-linolenic acid and tryptophan content in the $A$. sativum sprouts. An endogenous tryptophan metabolite, for example 5-methoxytryptophan (5-MTP), controls of COX-2 overexpression (Wu et al., 2014). The anti-inflammatory and pro-resolving properties of the n-3 fatty acids were observed in our previous studies (Gdula-Argasińska et al., 2015a; Gdula-Argasińska et al., 2015b; Gdula-Argasińska et al., 2016a; Gdula-Argasińska et al., 2016b). In Park and coworkers study (2014), ethyl linoleate, which is isolated from the cloves of $A$. sativum, down-regulated the inducible nitric oxide synthase (iNOS) and COX2 expression, thereby reducing the production of nitric oxide and prostaglandin E2 in the LPS-activated RAW 264.7 cells.

Garlic and different garlic extracts have been shown to have antioxidant activity in different in vitro models. The antioxidant activity of Allium plants has been mainly attributed to a variety of sulfur-containing compounds

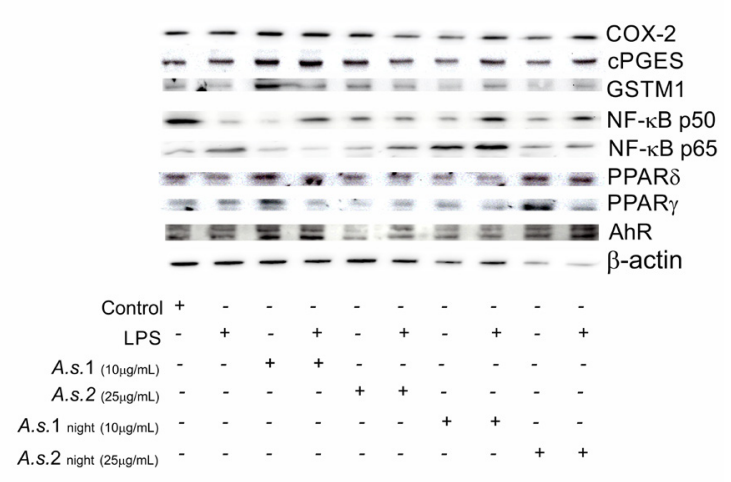

(B)

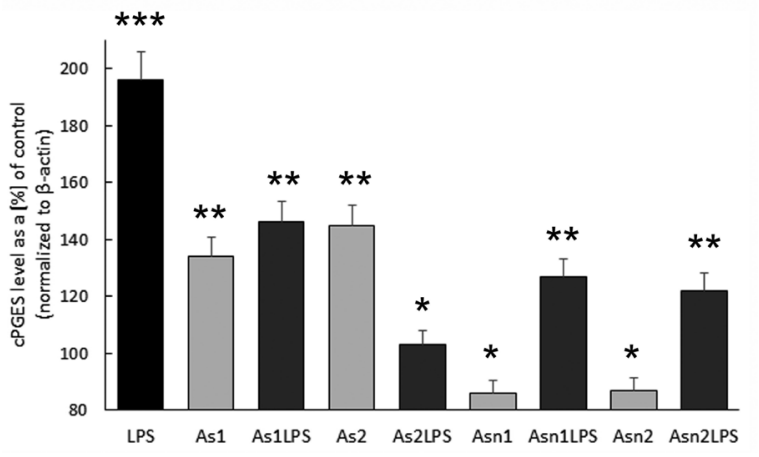

(D)

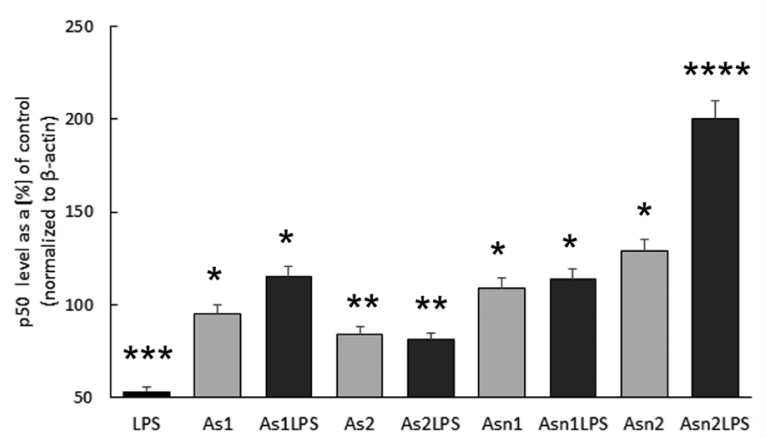

and their precursors (Nuutila et al., 2003; Queiroz et al., 2009).

In the study presented here, the GSTM1 level was statistically higher in all samples, both treated with garlic sprouts alone and activated with LPS $(p=0.001)$. A greater level of glutathione $\mathrm{S}$ transferase (GST) was noticed in the cells supplemented with $A$. sativum extracts obtained from sprouts grown under daylight ( $p=0.001$, Fig. 1C). The GST enzymes catalyze conjugation of xenobiotics to glutathione. GSTP1 and GSTM1 are mainly involved in detoxification reactions of carcinogenic intermediates produced by cytochrome P450 (CYP). Polymorphism of the GST genes may affect the level of carcinogen-DNA adducts in human tissues and may be associated with individual susceptibility to carcinogens (Butkiewicz et al., 2000).

In our study, a greater amount of cytosolic NF-кB p50 was observed in $A$. sativum extracts from sprouts cultivated in the dark and activated with LPS $(p=0.001)$. Also, higher of this unit of the transcription factor was observed in all cells treated with garlic extracts alone and activated with LPS (Fig. 1D). For the cytosolic NF-KB $\mathrm{p} 65$, a higher amount was observed in all macrophages

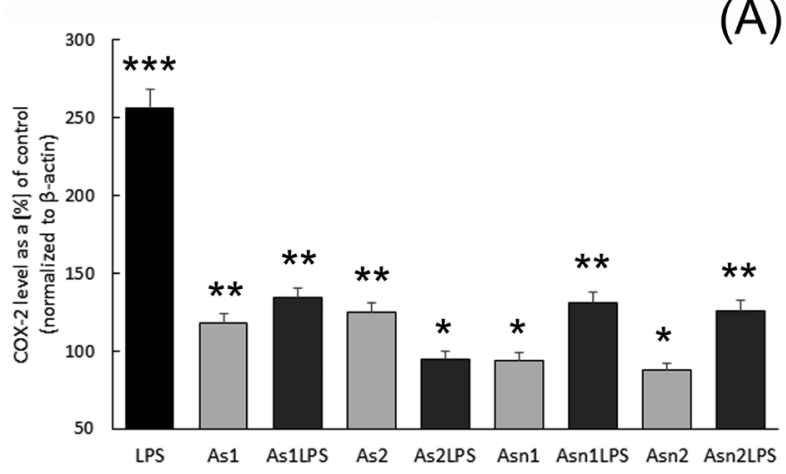

(C)

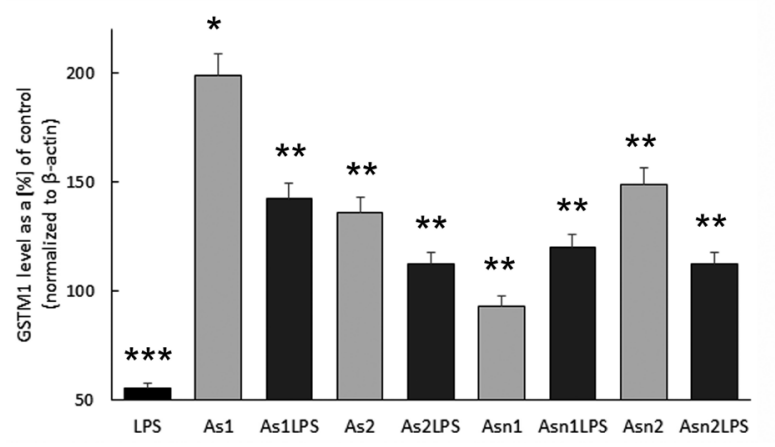

(E)

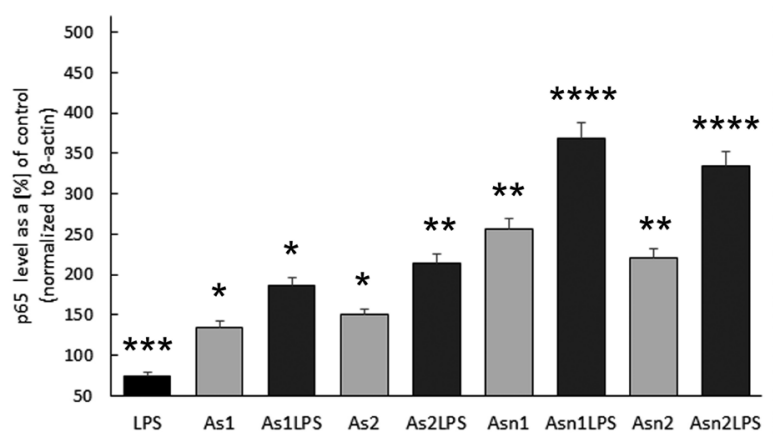


$(\mathrm{F})$

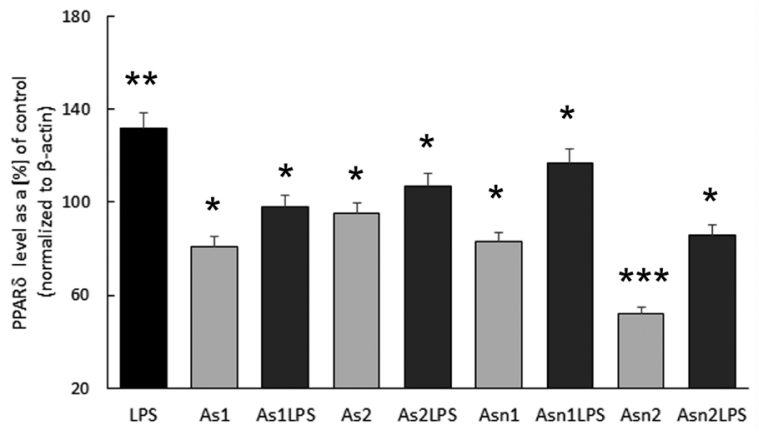

$(\mathrm{H})$

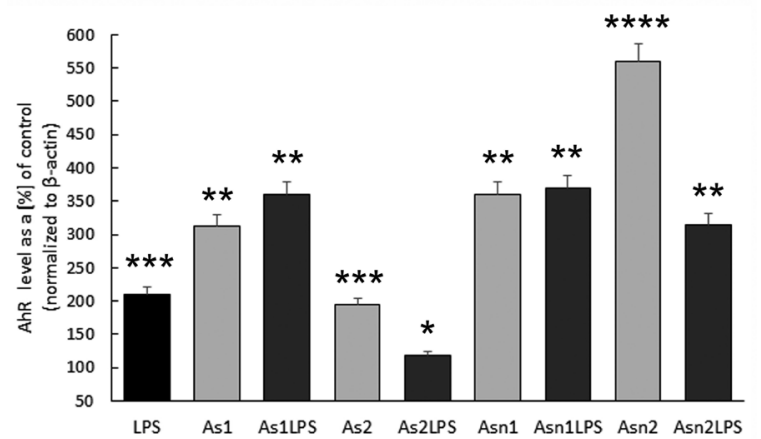

after incubation with garlic sprouts when compared to the LPS-activated cells $(p=0.001)$. Supplementation with both, extracts of garlic sprout grown in darkness and LPS, resulted in a greater level of p65 ( $p=0.005)$ (Fig. 1E). High amount of the two main units of transcription factor $\mathrm{NF}_{-\mathrm{K}} \mathrm{B}$ in the cytosol of cells after the garlic extract incubation, even though LPS activation suggested the suppression of translocation of p50 and p 65 to the nucleus, may be due to a high content of $\alpha$-linolenic acid in the extracts. After incubation of macrophages with LPS, the highest activity of the nuclear transcription factor $\mathrm{NF}_{-\mathrm{K}} \mathrm{B}$ p 65 and $\mathrm{p} 50$ was observed $(p=0.000)$. In the RAW 264.7 cells activated with LPS and incubated with garlic sprout extracts, the activity of p65 and p50 subunits of NF-kB was significantly lower $(p=0.000)$ (Fig. 2).

Inhibition of the NF-KB pathway may occur at several subsequent steps; extracellularly, free n-3 fatty acids inhibit activation of the Toll-like receptor by LPS. The $\alpha$-linolenic acid, as a precursor of EPA and DHA or its derivatives, may block the signaling cascade between Toll-like/cytokine receptors and the activator of $\mathrm{NF}_{-\mathrm{KB}} \mathrm{B}$ (Singer et al., 2008).

Peroxisome proliferator-activated receptors (PPARs) have emerged as links between lipids, metabolic diseases, and innate immunity. These transcription factors are activated by fatty acids and eicosanoids, many of which also signal through membrane receptors, creating a lipid signaling network between the cell membranes and the nucleus (Yang et al., 2013).

In our study, the highest level of cytosolic PPAR $\delta$ was noted in the LPS treated cells $(p=0.002)$. In RAW 264.7 cells supplemented with garlic sprouts and treated with LPS, the amount of this protein was lower $(p=0.004)$ (Fig. 1F). A greater level of cytosolic PPAR $\gamma$ was observed in cells incubated with $10 \mu \mathrm{g} / \mathrm{mL}$ garlic sprouts cultivated under daylight, as well as with $25 \mu \mathrm{g} / \mathrm{mL}$ garlic

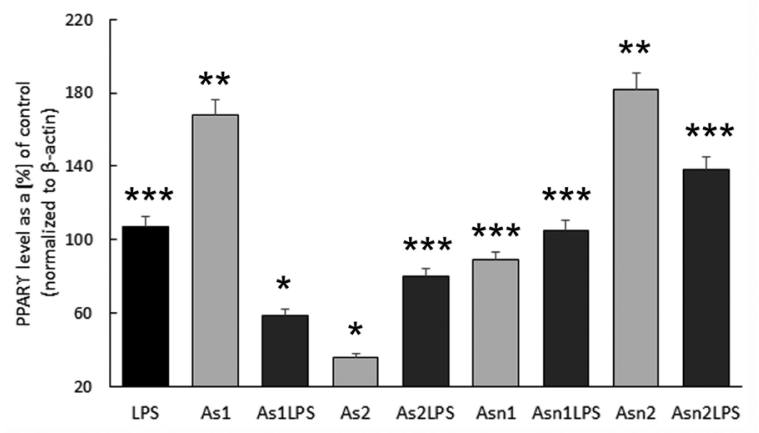

Figure 1. Relative level of COX-2 (A), CPGES (B), GSTM1 (C), NFKB p50 (D), NF-KB p65 (E), PPARס (F), PPARy (G), and AhR (H) in the RAW 264.7 cells activated with LPS and supplemented with garlic sprout extracts.

The graphs represent four independent experiments. Asterisks ${ }^{* * * * * * * * * * * *}$ denote statistical differences, $p<0.05$. A.s. 1 - Allium sativum extracts from sprouts grown under daylight $10 \mu \mathrm{g} / \mathrm{mL}$; A.s. 2 - Allium sativum extracts from sprouts grown under daylight 25 $\mu \mathrm{g} / \mathrm{mL}$; A.s. 1 night - Allium sativum extracts from sprouts grown in darkness $10 \mu \mathrm{g} / \mathrm{mL}$, A.s. 2 night - Allium sativum extracts from sprouts grown in darkness $20 \mu \mathrm{g} / \mathrm{mL}$

sprouts grown in the dark $(p=0.001)$ (Fig. 1G). Changes of the level of cytosolic PPARs in RAW 264.7 cells after garlic sprout extract treatment may be due to ahigh $\alpha$-linolenic content in the extracts. In Yang and coworkers work (2013), PPAR $\gamma$ activity and gene expression in human renal carcinoma cells were significantly increased by the $\alpha$-linolenic acid at 20 and $40 \mu \mathrm{mol}$, while COX2 activity and gene expression levels were significantly
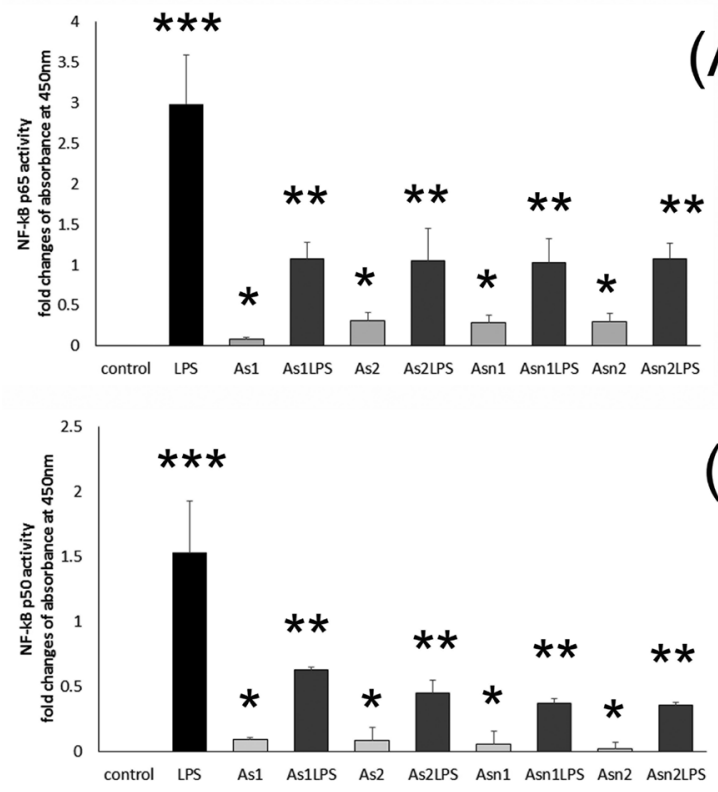

(B)

Figure 2. NF-kB p65 (A) and NF-kB p50 (B) transcription factor activities in RAW 264.7 cells supplemented with $A$. sativum extracts and/or LPS, expressed as fold changes when compared to the control cells.

Means \pm S.D. Asterisks ${ }^{* * *},{ }^{* * *}$ denote statistical significance, $p<0.05$ 
decreased by $\alpha$-linolenic acid beginning at $20 \mu \mathrm{mol}$. The lipid-activated transcription factor, PPAR $\gamma$, appears to have multiple functions in the immune system. Recent studies have highlighted a PPARs molecular transrepression mechanism in macrophages (Nagy et al., 2013).

In our study, a greater level of AhR was noted in the cells after supplementation with the garlic sprout extract from sprouts grown in darkness $(25 \mu \mathrm{g} / \mathrm{mL})$. The incubation of RAW 264.7 cells with $25 \mu \mathrm{g} / \mathrm{mL}$ of extract from garlic sprout cultivated under daylight, and activation with LPS, resulted in the lowest level of this protein $(p=0.02$, Fig. $1 \mathrm{H}) . \mathrm{AhR}$, as a nuclear factor, participates in the transcription factor $x \mathrm{~B}(\mathrm{NF}-x \mathrm{~B})$ signaling pathways regulating inflammation, immune responses, and other functions (Nguyen et al., 2013; Gdula-Argasińska et al., 2015b; Gdula-Argasińska et al., 2016a; Gdula-Argasińska et al., 2016b). Accumulating evidence suggests close interactions between $\mathrm{AhR}$ and $\mathrm{NF}_{-\mathrm{K}} \mathrm{B}$ pathways, and these interactions are potentially important mechanisms for many pathological processes, such as carcinogenesis and alteration of xenobiotic metabolism (Nguyen et al., 2013). Identification of endogenous AhR ligands is key to understanding the physiological functions of this transcription factor. Metabolites of the tryptophan and indolic compounds are AhR endogenous agonists (Hubbard et al., 2015).

\section{CONCLUSIONS}

Our study indicates a clear positive effect of light on the accumulation of indolic and phenolic compounds in garlic sprouts during their growth. The seeds showed low levels of the indole compounds, while the highest amounts were detected in sprouts. Yet, this level was higher in comparison to mature bulbs, which indicates a greater synthesis and accumulation of indole compounds at the stage of sprout growth. High amount of $\alpha$-linolenic acid (about $60 \%$ ) was observed in garlic sprouts obtained under daylight and darkness cultivating conditions.

A significant decrease in the level of COX-2 and cPGES was observed in the RAW 264.7 cells after incubation with garlic extracts. We observed a higher level of the GSTM1, NF-kB p50, and p65 cytosolic proteins, as well as AhR and PPAR $\delta$ after incubation with garlic extracts. It suggests transrepression via PPARs and AhR transcription factors, implying the inhibition of pro-inflammatory NF-kB signaling pathway. The obtained results indicate garlic sprouts as a rich source of alpha-linolenic acid, as well as indolic and phenolic compounds, characterized by anti-inflammatory and antioxidative activity, which may support their high therapeutic and dietary potential.

\section{Conflict of interest}

The authors declare no competing financial interest.

\section{Acknowledgements}

This project was supported by a Jagiellonian University Medical College grants: K/ZDS/006216, K/ ZDS/007076 and K/ZDS/005619.

\section{REFERENCES}

Alvarez-Suarez JM, Giampieri F, González-Paramás AM, Damiani E, Astolfi P, Martinez-Sanchez G, Bompadre S, Quiles JL, SantosBuelga C, Battino M (2012) Phenolics from monofl oral honeys protect human erythrocyte membranes against oxidative damage. Food Chem Toxicol 50: 1508-1516. doi: 10.1016/j.fct.2012.01.042

Anand R, Kaithwas G (2014) Anti-inflammatory potential of alphalinolenic acid mediated through selective COX inhibition: computational and experimental data. Inflammation 37: 1297-1306. doi: 10.1007/s10753-014-9857-6

Angiosperm Phylogeny Group (2009) An update of the Angiosperm Phylogeny Group classification for the orders and families of flowering plants: APG III. Bot J Linn Soc 161: 105-121

Bat-Chen W, Golan T, Peri I, Ludmer Z, Schwartz B (2010) Allicin purified from fresh garlic cloves induces apoptosis in colon cancer cells via Nrf2. Nutr Cancer 62: 947-957. doi: 10.1080/01635581.2010.509837

Benzie IF, Strain JJ (1996) The ferric reducing ability of plasma (FRAP) as a measure of "antioxidant power": the FRAP assay. Anal Biochem 239: 70-76. http://dx.doi.org/10.1006/abio.1996.0292

Butkiewicz D, Grzybowska E, Phillips DH, Hemminki K, Chorazy M (2000) Polymorphisms of the GSTP1 and GSTM1 genes and PAH-DNA adducts in human mononuclear white blood cells. Environ Mol Mutagen 35: 99-105. doi: 10.1002/(SICI)10982280(2000)35:2<99:AID-EM4>3.0.CO;2-2

Durak A, Ozturk HS, Olcav E, Güven C (2002) Effects of garlic extract supplementation on blood lipid and antioxidant parameters and atherosclerotic plaque formation process in cholesterol-fed rabbits. I Herb Pharmacother 2: 19-32. doi: 10.1300/j157v02n02_03

Durak I, Kavutcu M, Aytac B (2004) Effects of garlic extract consumption on blood lipid and oxidant/antioxidant parameters in humans with high blood cholesterol. J Nutr Biochem 15: 373-377. doi: 10.1016/j.jnutbio.2004.01.005

Edwards QT, Colquist S, Maradiegue A (2005) What's cooking with garlic: is this complementary and alternative medicine for hypertension? I Am Acad Nurse Pract 17: 381-385. doi: 10.1111/j.17457599.2005.00065.x

Ellnain-Wojtaszek M, Zgórka G (1999) High-performance liquid chromatography and thin-layer chromatography of phenolic acids from Ginkgo biloba L. leaves collected within vegetative period. J Liquid Chromatog Related Technolog 22: 1459-1471. http://dx.doi. org/10.1081/JLC-100101744

Esposito E, Cuzzocrea S (2010) Antiinflammatory activity of melatonin in central nervous system. Curr Neuropharmacol 8: 228-242. doi: 10.2174/157015910792246155

Gdula-Argasińska J, Garbacik A, Woźniakiewicz M, Paśko P, Czepiel J (2013) Identification of lipid derivatives in Hep G2 cells. Acta Biochim Pol 60: 811-815

Gdula-Argasińska J, Czepiel J, Woźniakiewicz A, Wojtoń K, Grzywacz A, Woźniakiewicz M, Jurczyszyn A, Librowski T, Perucki W (2015a) n-3 fatty acids as resolvents of inflammation in the A549 cells. Pharmacol Rep 67: 610-615. doi: 10.1016/j.pharep.2015.01.001

Gdula-Argasińska J, Czepiel J, Totoń-Żurańska J, Jurczyszyn A, Perucki W, Wołkow P (2015b) Docosahexaenoic acid regulates gene expression in HUVEC cells treated with polycyclic aromatic hydrocarbons. Toxicol Lett 236: 75-81. doi: 10.1016/j.toxlet.2015.05.002

Gdula-Argasińska J, Czepiel J, Totoń-Żurańska J, Jurczyszyn A, Perucki W, Wolkow P (2016a) n-3 Fatty acids regulate the inflammatorystate related genes in the lung epithelial cells exposed to polycyclic aromatic hydrocarbons. Pharmacol Rep 68: 319-328. doi: 10.1016/j. pharep.2015.09.001

Gdula-Argasińska J, Bystrowska B (2016b) Docosahexaenoic acid attenuates in endocannabinoid synthesis in RAW 264.7 macrophages activated with benzo(a)pyrene and lipopolysaccharide. Toxicol Lett 258: 93-100. doi: 10.1016/j.toxlet.2016.06.017

Graham J (2006) Purification of human erythrocyte 'ghosts'. In Cell Biology Protocols. Harris Jr, Graham J, Rick-Wood D eds, pp 137-138. John Wiley \& Sons, LTD., Chichester

Hubbard TD, Murray IA, Perdew GH (2015) Indole and tryptophan metabolism: endogenous and dietary routes to $\mathrm{Ah}$ receptor activation. Drug Metab Dispos 43: 1522-1535. doi: 10.1002/em.20474

Iciek M, Kwiecień I, Włodek L (2009) Biological properties of garlic and garlic-derived organosulfur compounds. Environ Mol Mutagen 50: 247-265. doi: $10.1002 / \mathrm{em} .20474$

Kamanna VS, Chandrasekhara N (1980) Fatty acid composition of garlic (Allium sativum Linnaeus) lipids. JAOCS 57: 175-176. doi: $10.1007 / \mathrm{BF} 02883781$

Kaneez FS, Arshad SS (2007) The metabolism of serotonin in neuronal cells in culture and platelets. Exp Brain Res 183: 411-416. doi: 10.1007/s00221-007-1133-7

Li QQ, Zhou SD, He XJ, Yu Y, Zhang YC, Wei XQ (2010) Phylogeny and biogeography of Allium (Amaryllidaceae: Allieae) based on nuclear ribosomal internal transcribed spacer and chloroplast rps16 sequences, focusing on the inclusion of species endemic to China. Ann Bot 6: 709-733. doi: 10.1093/aob/mcq177

Muszyńska B, Łojewski M, Sułkowska-Ziaja K, Szewczyk A, GdulaArgasińska J, Hałaszuk P (2016) In vitro cultures of Bacopa monnieri (L. Pennell) and an analysis of selected groups of biologically active metabolites in their biomass. Pharm Biol 4: 1-11. doi: $10.3109 / 13880209.2016 .11$ 
Muszyńska B, Maślanka A, Sułkowska-Ziaja K, Opoka W, Szopa A (2014) Analysis of 5-methyltryptamine, L-tryptophan, 5-hydroxy-Ltryptophan and melatonin in the bulbs of Allium sativum by TLC methods coupled with densitometric detection. I Planar Chromatogr. - Mod TLC 27: 210-216. doi: 10.1556/jpc.27.2014.3.11

Muszyńska B, Sułkowska-Ziaja K (2012) Analysis of indole compounds in edible Basidiomycota species after thermal processing. Food Chem 132: 455-459. doi: 10.1016/j.foodchem.2011.11.021

Muszyńska B, Sułkowska-Ziaja K, Ekiert H (2011) Indole compounds in fruiting bodies of some edible Basidiomycota species. Food Chem 125: 1306-1308. doi: 10.1016/j.foodchem.2010.10.056

Nagini S (2008) Cancer chemoprevention by garlic and its organosulfur compounds - panacea or promise? AntiCancer Agents Med Chem 8: 313-321. doi: 10.2174/187152008783961879

Nagy ZS, Czimmerer Z, Szanto A, Nagy L (2013) Pro-inflammatory cytokines negatively regulate $\operatorname{PPAR} \gamma$ mediated gene expression in both human and murine macrophages via multiple mechanisms. Immunobiology 218: 1336-1344. doi: 10.1016/j.imbio.2013.06.011

Nguyen NT, Hanieh H, Nakahama T, Kishimoto T (2013) The roles of aryl hydrocarbon receptor in immune responses. Int Immunol 25: 335-343. doi: 10.1093/intimm/dxt011

Nuutila AM, Puupponen-Pimia R, Aarni M, Oksman-Caldentey KM (2003) Comparison of antioxidant activities of onion and garlic extracts by inhibition of lipid peroxidation and radical scavenging activity. Food Chem 81: 485-493. doi: 10.1016/s0308-8146(02)00476-4

Park SY, Seetharaman R, Ko MJ, Kim Y, Kim TH, Yoon MK, Kwak JH, Lee SJ, Bae YS, Choi YW (2014) Ethyl linoleate from garlic attenuates lipopolysaccharide-induced pro-inflammatory cytokine production by inducing heme oxygenase-1 in RAW264.7 cells. Int Immunopharmacol 19: 253-261. doi: 10.1016/j.intimp.2014.01.017

Paśko P, Bartoń H, Zagrodzki P, Gorinstein S, Folta M, Zachwieja Z (2009) Anthocyanins, total polyphenols and antioxidant activity in amaranth and quinoa seeds and sprouts during their growth. Food Chem 115: 994-998. doi: 10.1016/j.foodchem.2009.01.037

Paśko P, Sułkowska-Ziaja K, Muszyńska B, Zagrodzki P (2014) Serotonin, melatonin, and certain indole derivatives profiles in rutabaga and kohlrabi seeds, sprouts, bulbs, and roots. LWT-Food Sci. Technology 59: 740-745. http://dx.doi.org/10.1016/j.lwt.2014.07.024
Paśko P, Gdula-Argasińska J, Podporska-Carroll J, Quilty B, WietechaPosłuszny R, Tyszka-Czochara M, Zagrodzki P (2015) Influence of selenium supplementation on fatty acids profile and biological activity of four edible amaranth sprouts as new kind of functional food. J Food Sci Technol 52: 4724-4736. doi: 10.1007/s13197-014-1602-5

Queiroz YS, Ishimoto EY, Bastos DHM, Sampaio GM, Torres EAFS (2009) Garlic (Allium sativum L.) and ready-to-eat garlic products: in vitro antioxidant activity. Food Chem 115: 371-374. doi: 10.1016/j. foodchem.2008.11.105

Serhan CN (2015) Pro-resolving lipid mediators are leads for resolution physiology. Nature 510: 92-101. doi: 10.1038/nature13479

Singer P, Shapiro H, Theilla M, Anbar R, Singer J, Cohen J (2008) Anti-inflammatory properties of omega-3 fatty acids in critical illness: novel mechanisms and an integrative perspective. Intensive Care Med 34: 1580-1592. doi: 10.1007/s00134-008-1142-4

Singhal NK, Srivastava G, Agrawal S, Jain SK, Singh MP (2012) Melatonin as a neuroprotective agent in the rodent models of Parkinson's disease: is it all set to irrefutable clinical translation? $\mathrm{Mol} \mathrm{Neu-}$ robiol 45: 186-199. doi: 10.1007/s12035-011-8225-x

Sovova M, Sova P (2004) Pharmaceutical importance of Allium sativum L. Hypolipemic effects in vitro and in vivo. Ceská a Slovenská farmacie 53: $117-123$

Stone TW, Mackay GM, Forrest CM, Clark CJ, Darlington LG (2003) Tryptophan metabolites and brain disorders. Clin Chem Lab Med 41: 852-859. doi: 10.1515/cclm.2003.129

Tin Y (2009) Ah receptor and NF-kB interplay on the stage of epigenome. Biochem Pharmacol 77: 670-680. doi: 10.1016/j.bcp.2008.10.023

Turner EH, Loftis JM, Blackwell AD (2006) Serotonin a la carte: Supplementation with the serotonin precursor 5-hydroxytryptophan. Pharmacol Ther 109: 325-338. doi: 10.1016/j.pharmthera.2005.06.004

Wu KK, Cheng HH, Chang TC (2014) 5-methoxyindole metabolites of L-tryptophan: control of COX-2 expression, inflammation and tumorigenesis. J Biomed Sci 3: 21-17. doi: 10.1186/1423-0127-21-17

Yang L, Yuan J, Liu L, Shi C, Wang L, Tian F, Liu F, Wang H, Shao C, Zhang Q, Chen Z, Qin W, Wen W (2013) $\alpha$-Linolenic acid inhibits human renal cell carcinoma cell proliferation through PPAR- $\gamma$ activation and COX-2 inhibition. Oncol Lett 6: 197-202. doi: $10.3892 / \mathrm{ol} .2013 .1336$ 